\title{
PENGARUH PENGEMASAN DAN PELABELAN PADA PENERIMAAN MI KERING BERBAHAN BAKU TEPUNG KOMPOSIT UBIJALAR DAN KELADI
}

\author{
Dian Adi Anggraeni Elisabeth \\ Indonesian Legume and Tuber Crops Research Institute (ILETRI) \\ e-mail: dian.elisabeth@litbang.pertanian.go.id
}

\begin{abstract}
Introduction of sweet potato and taro composite flours-based dried noodle production was conducted in Pelaga, Badung, Bali since 2013. Initial analysis found that dried noodle made from $70 \%$ wheat flour and $30 \%$ composite flours $180 \%$ taro flour and $20 \%$ sweet potato flour) was prefered by respondents. Minimum selling price for a pack of 200 grams was IDR $8,124.81$, with $R / C$ ratio was 1.30 . The product packaged with special design and set with the brand name of 'Labi Mie' then was introduced to consumers in order to determine their acceptance to the product. The study involved 32 respondents. Data was collected from semi-open questionnaires then analyzed with a simply descriptive qualitative. Consumers stated that the information of expired date and net weight (75,00\%) as well as nutrition fact $(34,38 \%)$ were unclear. As much as $68,75 \%$ consumers had no intention to buy the product with the reason of high price (50,00\%) and unattractive $(27,27 \%)$. The price of IDR 8,500 was considered too expensive by consumers. It should be less or equal to IDR $8,000.00$ (87,50\%). Only 6,25\% consumers answered that reasonable price could be higher than minimum selling price. It should be admitted that these study results were still far from the expectation. However, it is a valuable input for farmers in developing their product in market.
\end{abstract}

Keywords: composite flours-based dried noodle, consumers' acceptance, packaging, product development

\begin{abstract}
ABSTRAK
Introduksi produksi mi kering berbahan baku tepung komposit ubijalar dan keladi dilaksanakan di Pelaga, Badung, Bali sejak 2013. Hasil penelitian pendahuluan menunjukkan bahwa mi kering yang dibuat dari $70 \%$ tepung terigu dan $30 \%$ tepung komposit dengan perbandingan $80 \%$ tepung keladi dan $20 \%$ tepung ubijalar disukai oleh panelis. Harga jual minimum untuk mi kering kemasan 200 gram adalah Rp 8.124,81 dengan $\mathrm{R} / \mathrm{C}$ rasio 1,30 . Produk mi dikemas dengan desain khusus dan diberi label nama "Labi Mie" kemudian diperkenalkan kepada konsumen untuk mengetahui tingkat penerimaan mereka terhadap produk. Studi melibatkan 32 orang responden. Data dikumpulkan melalui kuesioner semi-terbuka, kemudian dianalisis secara deskriptif kualitatif sederhana. Konsumen menyatakan bahwa informasi tanggal kadaluwarsa dan berat bersih produk tidak jelas $(75,00 \%)$, demikian juga daftar kandungan gizi (34,38\%). Sebanyak $68,75 \%$ konsumen menyatakan tidak berminat membeli produk karena alasan harga mahal $(50,00 \%)$ dan produk tidak menarik $(27,27 \%)$. Harga jual sebesar Rp 8.500 per kemasan 200 gram dinilai konsumen terlalu mahal. Harga jual seharusnya kurang atau sama dengan Rp 8.000 (87,50\%). Hanya 6,25\% konsumen yang menjawab bahwa harga yang pantas
\end{abstract}


untuk produk adalah lebih tinggi dari harga jual minimum. Harus diakui bahwa hasil studi masih jauh dari perkiraan; namun hal tersebut dapat menjadi masukan bagi petani dalam mengembangkan produknya di pasaran.

Kata kunci: mi kering berbahan baku tepung komposit, penerimaan konsumen, pengemasan, pengembangan produk

Untuk memastikan keberhasilan suatu produk pangan di pasar, industri pangan harus memahami penerimaan konsumen terhadap atribut-atribut sensori dan non-senssori produk pangan tersebut. Pada beberapa studi, atribut sensori masih merupakan faktor paling penting untuk mengevaluasi penerimaan konsumen terhadap produk pangan. Namun, pada kenyataannya atribut non-sensori juga memberikan pengaruh yang tidak kalah pentingnya pada penerimaan konsumen. Beberapa studi pada berbagai produk menunjukkan bahwa pengemasan dan pelabelan memberikan dampak yang besar pada keputusan konsumen untuk membeli suatu produk (Kuvykaite, Dovaliene, dan Navickiene, 2009; Moreno, Parmar, dan Amin, 2011; Ahmed, Parmar, dan Amin, 2014; Ampuero dan Vila, 2016). Juga telah diketahui akhir-akhir ini, atribut nonsensori ini semakin berperan penting pada pengembangan produk pangan.

Selain mempengaruhi penerimaan konsumen, atribut sensori nampaknya juga mempengaruhi ekspektasi konsumen terhadap atribut sensori dan hedonik (kesukaan). Ekspektasi tersebut biasanya terbentuk sebelum konsumen mencoba produk pangan. Pada ekspektasi sensori,konsumen akan mempunyai gambaran tentang karakteristik sensori yang mungkin diterimanya dan pada ekspektasi hedonik, konsumen akan dapat mengetahui seberapa besar mereka akan menyukai produk pangan tersebut (Moreno et al., 2011). Lebih lanjut, Varela et al. dalam Moreno et al. (2011) menyebutkan bahwa kedua ekspektasi tersebut terbentuk setelah konsumen melihat sendiri penampilan produk terutama pengemasan dan pelabelan.

Fungsi pengemasan pada saat ini telah berubah sejalan dengan perubahan gaya hidup konsumen yang cenderung bersifat self service. Pengemasan berperan sebagai sarana promosi penjualan yang dapat menstimulasi kebiasaan belanja konsumen sehingga dapat mengurangi biaya promosi yang tinggi (Kuvykaite, Dovaliene, dan Navickiene. 2009). Kemasan menjadi daya tarik bagi konsumen dan mempengaruhi persepsi mereka tentang produk (Rundh, 2005).

Introduksi pengolahan mi kering dari substitusi sebagian tepung terigu dengan tepung komposit ubijalar dan keladi dilakukan oleh Balai Pengkajian Teknologi Pertanian (BPTP) Bali di Desa Pelaga, Kabupaten Badung, Bali dengan melibatkan kelompok wanita tani Mekar Sari pada tahun 2013 dan 2014. Beberapa hasil penelitian pendahuluan mi kering dari tepung komposit ini adalah sebagai berikut: (1) Formula pembuatan mi kering berasal dari Iptek.net (Kamus IImiah, 2013), dimana tepung komposit mensubstitusi 30\% penggunaan tepung terigu (Elisabeth dan Suwarno, 2014). Hasil uji sensori dari mi kering dengan perbandingan $80 \%$ tepung keladi dan $20 \%$ tepung ubijalar dalam tepung komposit menghasilkan penerimaan terbaik oleh panelis dari segi warna, kelengketan, dan penerimaan secara keseluruhan, namun tidak berbeda nyata dengan perlakuan komposisi tepung komposit lainnya dari segi aroma, rasa, tekstur, dan kekenyalan (Elisabeth et al., 2013); (2) Hasil analisis ekonomi menunjukkan harga jual minimum mi kering tepung komposit adalah Rp 8.124,81 untuk kemasan $200 \mathrm{~g}$, dengan $\mathrm{R} / \mathrm{C}$ ratio 1,30 sehingga produk layak dikembangkan oleh petani (Rinaldi, Aurum, dan Elisabeth 2016); dan (3) Penyimpanan mi kering tepung komposit yang sesuai adalah dalam plastik polietilen (PE) 0,35 
$\mathrm{mm}$, dimana hasil analisis umur simpan menunjukkan bahwa pada penyimpanan suhu ruang, umur simpan mi kering dapat mencapai sekitar 46 minggu (Elisabeth dan Setijorini,2016).

Produk mi kering yang diproduksi oleh kelompok wanita tani Mekar Sari kemudian dikemas menggunakan plastik PE 0,35 mm yang telah didesain secara khusus, diberi label produk, dan menggunakan nama "Labi Mie" sebagai nama produk. Produk kemudian diperkenalkan kepada konsumen. Penelitian ini bertujuan untuk mengetahui penerimaan konsumen terhadap produk mi kering tepung komposit dengan melakukan pengamatan terhadap kemasan dan informasi yang terdapat pada kemasan (labelling).

\section{METODE}

\section{Sampel Konsumen}

Studi melibatkan 32 responden sesuai dengan jumlah sampel minimal 30 responden (Nawawi, 1995). Metode pemilihan responden adalah accidental sampling (Sugiyono, 2004) pada saat pameran peringatan Kemerdekaan RI ke-69 di Art Center Denpasar, Bali pada 14-23 Agustus 2014. Responden yang didapatkan selama pameran terdiri dari swasta $(34,38 \%)$, pelajar dan mahasiswa (25\%), PNS (25\%), ibu rumah tangga (9,38\%), dan petani $(6,25 \%)$. Umur responden berkisar 13 sampai 46 tahun, dengan $25 \%$ responden berumur kurang dari 25 tahun dan $75 \%$ berumur lebih atau sama dengan 25 tahun. Jenis kelamin responden adalah $53,12 \%$ pria dan $46,88 \%$ wanita.

\section{Tes Konsumen}

Produk mi kering diproduksi oleh kelompok wanita tani Mekar Sari di Desa Pelaga, Kabupaten Badung, Bali. Produk yang telah dikemas dalam plastik PE 0,35 mm yang didesain khusus, diberi label yang dicetak pada stiker, dan menggunakan nama "Labi Mie" kemudian dievaluasi oleh responden dengan mengamati desain dari kemasan, informasi produk yang terdapat pada kemasan, dan harga jual produk dengan menggunakan metode expected (Moreno et al. 2011). Panduan pengamatan produk menggunakan kuesioner semi-terbuka.

Informasi produk yang terdapat pada kemasan meliputi nama produk (bagian depan kemasan); serta ingredien, informasi gizi, dan nama/alamat produsen (bagian belakang kemasan). Penerimaan responden terhadap desain kemasan dievaluasi dengan tiga skala preferensi, yaitu $1=$ tidak suka, 2 = agak suka, dan 3 = suka. Informasi pada kemasan (labelling) dievaluasi dengan tiga skala, yaitu 1 = tidak jelas, 2 = agak jelas, dan 3 = jelas. Minat responden untuk membeli produk dievaluasi dengan dua skala yaitu 1 = tidak berminat membeli dan 2 = berminat membeli. Sementara penerimaan terhadap harga jual produk dievaluasi dengan dua skala yaitu $1=$ harga tidak sesuai dan 2 = harga sesuai. Data yang diperoleh kemudian dianalisis secara deskriptif kualitatif sederhana dan disajikan dalam bentuk tabel dan grafik.

\section{HASIL DAN PEMBAHASAN}

\section{Penerimaan Responden pada Kemasan dan Labelling}

Rata-rata penerimaan responden terhadap desain kemasan adalah $2,47 \pm 0,76$, yaitu berkisar dari agak suka sampai suka. Persentase penerimaan responden terhadap desain kemasan seperti dapat dilihat pada Gambar 1. Responden menyebutkan bahwa kemasan memiliki warna yang menarik. Namun, responden lebih suka jika desain kemasan dapat langsung dicetak pada plastik PE dibandingkan dicetak pada stiker label yang kemudian ditempelkan pada plastik PE. 


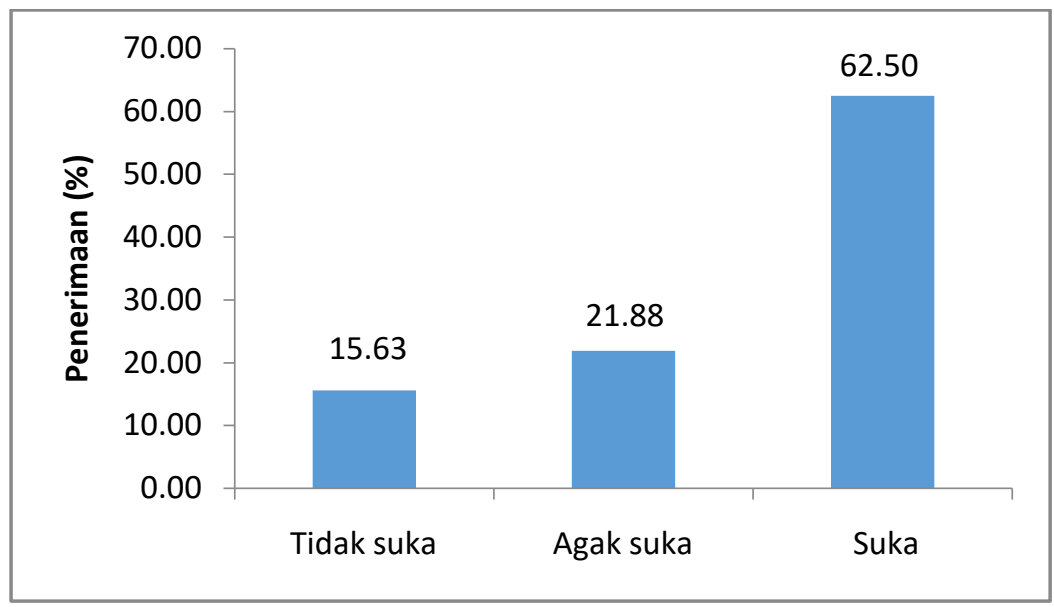

Gambar 1. Persentase penerimaan responden terhadap desain kemasan produk mi kering

Informasi produk terkait tanggal kadaluwarsa dan berat bersih dianggap responden tidak jelas, berturut-turut sebesar $90,63 \%$ dan 75,00\% (Tabel 1). Rata-rata hasil evaluasi untuk informasi tanggal kadaluwarsa dan berat bersih adalah berturut-turut sebesar 1,16 $\pm 0,51$ dan 1,41 $\pm 0,76$ yang berarti berkisar antara tidak jelas sampai agak jelas. Sekitar $34,38 \%$ mengatakan informasi tambahan seperti informasi gizi dan kesehatan juga masih belum jelas. Almatsier dalam Devi, Sartono, dan Isworo (2013) menyebutkan jika produk pangan yang dikemas perlu dilengkapi dengan label yang di dalamnya berisi informasi ingredien, komposisi produk, tanggal kadaluwarsa, informasi gizi dan rekomendasi gizi yang dianjurkan serta informasi penting lainnya sepeti label halal, dan lain-lain.

Tabel 1. Penerimaan Responden Terhadap Informasi Kemasan/Labelling ( $\mathrm{N}=32$ ).

\begin{tabular}{lcrcc}
\hline \multirow{2}{*}{ Jenis informasi } & Rata-rata & \multicolumn{3}{c}{ Persentase penerimaan (\%) } \\
\cline { 3 - 5 } & penerimaan & Jelas & Agak jelas & Tidak jelas \\
\hline Tanggal kadaluwarsa & $1,16 \pm 0,51$ & 3,12 & 6,25 & $\mathbf{9 0 , 6 3}$ \\
Nama/alamat produsen & $2,88 \pm 0,49$ & $\mathbf{9 3 , 7 5}$ & 0,00 & 6,25 \\
Berat bersih produk & $1,41 \pm 0,76$ & 15,62 & 9,38 & $\mathbf{7 5 , 0 0}$ \\
Informasi tambahan & $2,09 \pm 0,89$ & $\mathbf{4 3 , 7 5}$ & 21,87 & 34,38 \\
\hline
\end{tabular}

Peraturan Pemerintah No.69/1999 tentang Labelling dan Iklan Produk Pangan menyebutkan bahwa label pangan harus memuat setidaknya nama produk, ingredien, berat bersih, nama/alamat produsen, serta tanggal kadaluarsa. Lebih lanjut, Maflaha (2012) mengatakan bahwa informasi minimal pada produk pangan tradisional yang dikemas adalah ingredien, nama produsen, dan tanggal kadaluarsa.

Berdasarkan pernyataan tersebut, harus diakui jika beberapa informasi pada kemasan mi kering belum sesuai dengan peraturan yang berlaku bahkan dengan informasi minimal, sehingga perlu dilakukan perbaikan.

'Kemasan adalah produk' merupakan istilah yang umum pada marketing produk (Maflahah, 2012). Kemasan menjadi sarana promosi penjualan (Kuvykaite, Dovaliene, dan. Navickiene, 2009; Ahmed, Parmar, dan Amin, 2014), yang berperan penting pada keputusan 
konsumen membeli suatu produk (Ksenia, 2013; Ahmed, Parmar, dan Amin, 2014). Stewart (2004) mendefinisikan tiga fungsi primer kemasan, yaitu untuk mewadahi, untuk melindungi, dan untuk identitas produk. Fungsi identitas produk adalah untuk menyediakan informasi produk bagi konsumen dan sebagai alat promosi yang dapat menstimulasi keinginan untuk membeli produk. Jika informasi pada kemasan tidak jelas seperti yang dibayangkan oleh konsumen, kemungkinan dapat menyebabkan minat beli produk menjadi rendah.

Hal tersebut juga terjadi pada sejumlah 22 responden $(68,75 \%)$ yang menyatakan tidak berminat membeli produk (Gambar 2.a). Jumlahnya mencapai dua kali lipat dari mereka yang berminat membeli $(31,25 \%)$, dengan rata-rata minat beli adalah $1,31 \pm 0,47$. Sekitar 7 responden $(27,27 \%)$ yang tidak berminat membeli produk beralasan jika rendahnya minat beli mereka adalah karena produk yang tidak menarik (Gambar 2.b).

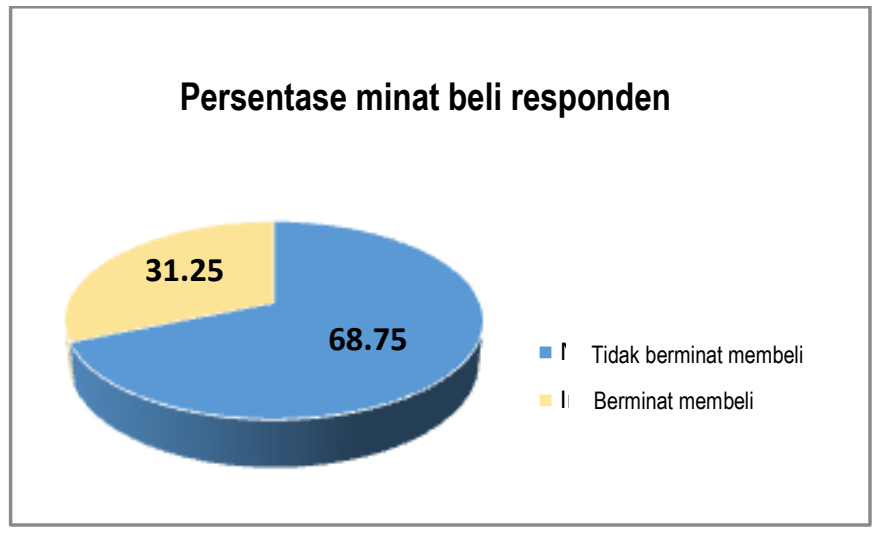

(a)

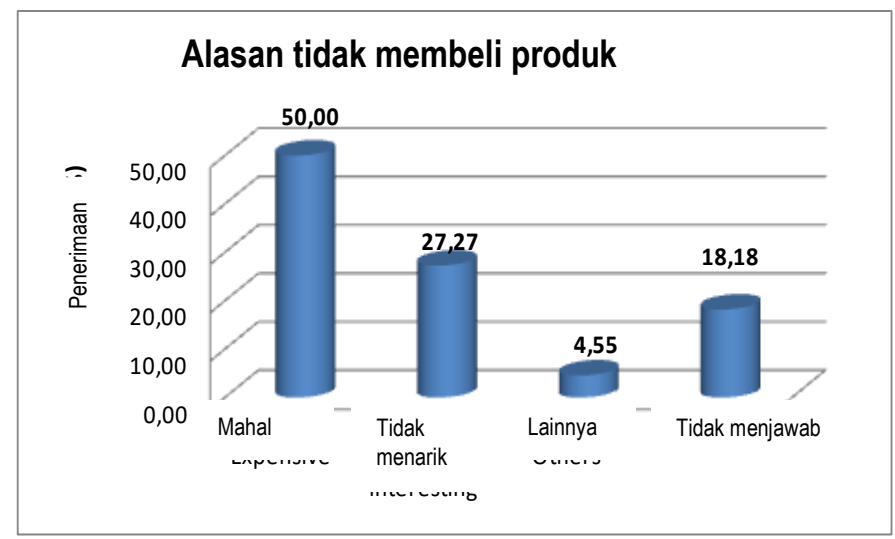

(b)

Gambar 2. (a) Persentase minat beli responden ( $n=32)$;

(b) Persentase alasan responden yang tidak berminat membeli produk ( $\mathrm{n}=22)$

Labelling yang baik pada kemasan produk akan mempengaruhi minat beli konsumen, namun tetap ada faktor lain yang dapat mempengaruhi (Saeed et al. 2013). Gambar 2.b 
menunjukkan harga yang mahal sebagai alasan lain responden tidak berminat membeli produk, dan nampaknya hal tersebut merupakan alasan yang utama $(50,00 \%)$. Alasan responden tidak berminat membeli produk karena harga yang mahal berkaitan juga dengan penerimaan responden pada harga jual produk. Rata-rata penerimaan responden terhadap harga jual adalah 1,25 0,44. Sekitar 75,00\% responden menyatakan bahwa harga jual sebesar $\mathrm{Rp} 8.500,00$ untuk produk mi kering adalah tidak sesuai (Tabel 2). Harga jual mi kering dari tepung komposit ini memang relatif lebih mahal jika dibandingkan mi kering dari 100\% tepung terigu yang sudah biasa dipasarkan di toko-toko yaitu berkisar Rp 3.000,00 sampai Rp 4.000,00, atau berarti hanya separuh dari harga mi kering dari tepung komposit. Oleh karena itu, sebanyak $87,50 \%$ responden menyebutkan bahwa harga yang pantas/sesuai untuk produk mi kering dari tepung komposit ini adalah kurang atau sama dengan Rp 8.000,00 (Tabel 2).

Tabel2. Penerimaan Responden pada Harga Jual Produk Sebesar Rp 8.500,00a) (N=32).

\begin{tabular}{lc}
\hline \multicolumn{1}{c}{ Deskripsi } & Persentase (\%) \\
\hline Harga jual Rp 8.500,00a): & 25,00 \\
a. Sesuai & 75,00 \\
b. Tidak sesuai & \\
\hline Harga jual yang pantas/sesuai menurut responden: & 87,50 \\
a. <= Rp 8.000,00 & 8,33 \\
b. > Rp 8.000,00 & 4,17 \\
C. Tidak menjawab & \\
\hline
\end{tabular}

Keterangan:

a) Berdasarkan harga jual minimum mi kering berbahan baku tepung komposit keladi dan ubijalar kemasan 200 g, yaitu Rp 8.124,81 (Rinaldi, Aurum, dan Elisabeth, 2016).

Hasil studi tentang penerimaan konsumen harus diakui masih jauh dari hasil yang diharapkan. Namun, kegiatan introduksi yang telah dilakukan, baik introduksi pengolahan produk pada petani dan introduksi produk pada konsumen harus tetap dilakukan sebagai salah satu bentuk usaha mempromosikan pemanfaatan pangan lokal untuk mengurangi ketergantungan pada penggunaan tepung terigu yang sampai saat ini pemenuhan kebutuhannya terutama masih berasal dari impor, sementara gandum sendiri tidak dapat dibudidayakan dengan baik di Indonesia.

Susanto dalam Kasno, Saleh, dan Ginting (2006) menyatakan bahwa pangan dan gizi bersifat pribadi tergantung pada masing-masing individu. Namun, masyarakat perlu memiliki pengetahuan tentang pangan lokal yang beragam untuk membangkitkan apresiasi, penerimaan, dan keinginan untuk mengkonsumsi pangan lokal sehingga dapat mencegah ketergantungan pada satu atau dua jenis pangan pokok tertentu. Mengubah pola pikir masyarakat terkait komoditas nonberas terutama dari aneka kacang dan umbi yang seringkali dianggap sebagai komoditas kelas dua perlu dilakukan melalui pengembangan produk dengan memanfaatkan teknologi pengolahan pangan, bahkan yang sederhana sekalipun sehingga dapat menghasilkan produk pangan baru yang menarik, bergizi, dan memiliki manfaat kesehatan.

Pangan yang dikonsumsi oleh individu, keluarga, maupun masyarakat memiliki keterkaitan erat dengan sikap dan perilaku. Oleh karena itu, kebijakan pangan di Indonesia tidak hanya selalu didasarkan pada persediaan dan kebutuhan pangan pokok, namun juga pada sikap dan perilaku masyarakat terkait pangan. Kasno, Saleh, dan Ginting (2006) menambahkan jika sikap dan 
perilaku masyarakat tidak mulai diperbaiki, Indonesia akan memiliki masalah yang lebih besar terkait pangan di masa mendatang.

\section{Masukan Responden untuk Perbaikan Pengembangan Produk}

Untuk perbaikan produk, responden memberikan beberapa masukan yang kemudian dikelompokkan ke dalam dua grup, yaitu masukan terkait labelling dan desain kemasan (Tabel 3). Masukan untuk labelling yang terutama adalah tentang informasi tanggal kadaluwarsa produk $(34,29 \%)$. Masukan tersebut nampaknya sesuai dengan hasil penerimaan responden terhadap labelling pada Tabel 1 yang menyebutkan bahwa informasi tanggal kadaluwarsa produk tidak jelas $(90,63 \%)$. Responden mengamati bahwa informasi berat bersih produk dan perijinan dari Dinas Kesehatan juga penting (masing-masing 17,14\%). Berat bersih produk merupakan informasi primer yang disyaratkan sesuai Peraturan Pemerintah No. 69/1999. Informasi perijinan dari Dinas Kesehatan diminta oleh responden untuk dicantumkan untuk memastikan bahwa produk aman untuk dikonsumsi dan memiliki manfaat kesehatan.

Tabel 3. Masukan Responden untuk Pengembangan Produk.

\begin{tabular}{lc}
\multicolumn{1}{c}{ Masukan responden } & $\begin{array}{c}\text { Persentase jawaban } \\
(\mathrm{n}=32)\end{array}$ \\
\hline Terkait informasi produk/labelling: & \\
a. Tanggal kadaluwarsa & 34,29 \\
b. Manfaat kesehatan & 5,71 \\
c. Berat bersih & 17,14 \\
d. Perijinan dari Dinas Kesehatan & 17,14 \\
e. Komposisi produk & 2,86 \\
f. Tanggal produksi & 11,43 \\
g. Informasi gizi & 2,86 \\
\hline Terkait desain kemasan: & \\
a. Kecerahan warna & 2,86 \\
b. Gambar produk pada kemasan & 2,86 \\
c. Label dicetak pada kemasan & 2,86 \\
\hline
\end{tabular}

Terkait desain kemasan, responden memberikan masukan untuk menggunakan warna yang lebih cerah, menambahkan gambar produk, dan mencetak label produk langsung pada kemasan. Ksenia (2013) menyebutkan bahwa kemasan yang eye-catching memiliki peluang untuk diperhatikan dan kemudian dibeli oleh konsumen. Penggunaan gambar pada kemasan bersifat lebih efektif dibandingkan teks/kata-kata (Underwood, Klein, dan Burke, 2001) karena konsumen cenderung lebih cepat mengolah informasi visual dibandingkan informasi dalam bentuk kata-kata (Gofman, Moskowitz, dan Mets dalam Ksenia, 2013).

Hasil studi penerimaan responden ini dapat menjadi masukan yang baik bagi kelompok wanita tani yang memproduksi mi kering tepung komposit untuk mengembangkan produknya lebih lanjut di pasaran. Informasi tambahan pada kemasan produk terutama yang terkait dengan informasi gizi dan manfaat kesehatan dari produk mi kering berbahan baku tepung komposit keladi dan ubijalar diharapkan dapat meningkatkan penerimaan konsumen terhadap produk meskipun harga jual produk lebih tinggi daripada harga jual mi kering dari $100 \%$ tepung terigu. 


\section{SIMPULAN}

Penerimaan responden terhadap kemasan dan labelling produk mi kering berbahan baku tepung komposit keladi dan ubijalar masih rendah. Responden mendapati bahwa beberapa informasi seperti tanggal kadaluwarsa dan berat bersih produk masih belum jelas. Hal ini menyebabkan responden tidak berminat membeli produk, disamping karena alasan harga produk

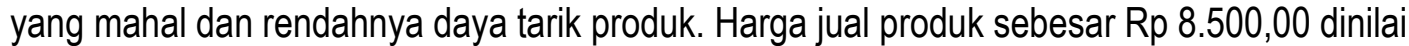
responden terlalu mahal. Responden menilai harga yang pantas/sesuai untuk produk adalah kurang atau sama dengan Rp 8.000,00. Hanya 6,25\% responden yang menjawab harga yang pantas/sesuai untuk produk adalah di atas harga jual minimum. Harus diakui bahwa hasil studi masih jauh dari yang diharapkan. Namun, introduksi kegiatan pengolahan pada petani dan introduksi produk pada konsumen tetap harus dilakukan sebagai salah satu usaha untuk mempromosikan pemanfaatan pangan lokal. Hasil studi dapat menjadi masukan berharga bagi kelompok wanita tani dalam mengembangkan produk mereka di pasaran.

\section{REFERENSI}

Ahmed, R. R., V. Parmar, \& M. A. Amin. (2014). Impact of product packaging on consumer's buying behavior. European journal of scientific research, 120(2): 145-157.

Ampuero, O. \& N. Vila. (2016). Consumer perceptions of product packaging. Journal of Consumer Marketing, vol. 23(2): 102-114.

Devi, V. C., A. Sartono, \& J.T. Isworo. (2013). Praktek pemilihan makanan kemasan berdasarkan tingkat pengetahuan tentang label produk makanan kemasan, jenis kelamin, dan usia konsumen di pasar swalayan ADA Setiabudi Semarang. Jurnal Gizi, vol. 2(2): 1-12.

Elisabeth, D.A.A., \& M. Suwarno. (2014). Dried noodle processing with taro and sweet potato composite flour. Prosiding. PATPI International Conference: Food for a Quality Life. SouthEast Asia FoodAgricultural Scienceand Technology (SEAFAST), Institut Pertanian Bogor, hal. 213-226.

Elisabeth, D.A.A. \& Setijorini, L.E. (2016). Pendugaan umur simpan mi kering dari tepung komposit terigu, keladi, dan ubijalar. Jurnal Matematika Sains dan Teknologi Universitas Indonesia, vol.17(1):20-28.

Elisabeth, D.A.A., Ni K.T.A. Yanti, M. Sugianyar, \& F.S. Aurum. (2013). Introduksi teknologi pengolahan tepung komposit keladi dan ubijalar. Laporan akhir (Tidak dipublikasikan). KKP3SL BPTP Bali, Proyek SMARTD, Balitbangtan Pertanian, 42 hal.

Kamus IImiah. (2013). Teknologi pembuatan mie skala industri rumah tangga. Tersedia dalam www.kamusilmiah.com/teknologi/teknologi-pembuatan-mie-skala-industri-rumah-tangga (Diakses pada 18 Januari 2013).

Kasno, A., N. Saleh, \& E. Ginting. (2006). Pengembangan pangan berbasis kacang-kacangan dan umbi-umbian guna pemantapan ketahanan pangan nasional. Buletin Palawija, no. 12, hal.43-51.

Ksenia, P. (2013). Packaging design as a market tool and desire to purchase. Skripsi. Fakultas Administrasi Bisnis, Lappeenranta, Universitas IImu Terapan Saimaa.

Kuvykaite, R., A. Dovaliene, \& L. Navickiene. (2009). Impact of package elements on consumer's purchase decision. Economics and Management, vol. 14, hal. 441-447.

Maflahah, I. (2012). Desain kemasan makanan tradisional Madura dalam rangka pengembangan IKM. Agrointek, vol. 6(2): 118-122. 
Moreno, M. T., A. Tarrega, E. Torrescasana, \& C. Blanch. (2011). Influence of label information on dark chocolate acceptability. Laporan penelitian. Appetite (2011), doi:10.1016/ j.appet.2011.12.005.

Nawawi, H. (1995). Metode penelitian bidang sosial. Edisi ke-7. Yogyakarta: Universitas Gajahmada Press.

Rinaldi, J., F.S. Aurum, \& D.A.A. Elisabeth. (2016). Nilai tambah pengolahan keladi dan ubijalar menjadi mi kering. Prosiding. Seminar Nasional Hasil Penelitian Tanaman Aneka Kacang dan Umbi, Balitkabi, Malang, 19 Mei 2015, hal. 685-691.

Rundh, B. (2005). The multi-faceted dimension of packaging: marketing logistic or marketing tool? British Food Journal, vol. 107(9): 670-684.

Saeed, R., R.N. Lodhi, A. Rauf, M.I. Rana, Z. Mahmood, \& N. Ahmed. (2013). Impact of labeling on customer buying behavior in Sahiwal Pakistan. World applied sciences journal, vol. 24(9): 1250-1254.

Stewart, B. (2004). Packaging design strategies. Edisi ke-2. The UK: Pira International Ltd., 176 hal.

Sugiyono. (2004). Metode penelitian bisnis. Edisi ke-9. Bandung: CV. Alfabeta.

Underwood, R. L. , N. M. Klein, \& R. R. Burke. (2001). Packaging communication: attentional effects of product imagery. Journal of Product \& Brand Management, vol.10(2): 403-422. 